\title{
Change of Income from Forest Products based on Geographical Location of Enterprises and some Marketing Variables
}

\author{
Orman Ürünlerinden Să̆lanan Gelirlerin İşletmelerin Cŏgrafi Konumu ve Bazı Pazar \\ Değişkenlerine Göre Değişimi
}

\author{
Osman KOMUT*a, Serpil SANTO ${ }^{\mathrm{b}}$ \\ Gümüşane University, Institute of Natural Applied Science, Department of Forestry and Environment Sciences, 29100, Gümüşhane, \\ Turkey
}

• Geliș tarihi / Received: 09.04.2020 • Düzeltilerek geliş tarihi / Received in revised form: $31.05 .2020 \quad$ • Kabul tarihi / Accepted: 03.06 .2020

\begin{abstract}
The Turkey forest products market losing its monopoly property has led to a reduction in the income of General Directorate of Forestry (GDF). Forest Enterprises Directorate (FED) regulate the wood sale revenue separately and the success level of each managements is considered as separately. In this study, some factors affecting the sale price of wood based products for General Directorate of Forestry are analyzed. In this context, the results of the 5-year wood sale revenue sale auctions between the years 2014-2018 of 2 Regional Directorate of Forests (RDF), which are close to each other in terms of geographical location, and 21 FEDs operating under them are analyzed. Evaluations were conducted on the basis of stumpage sales and traditional warehouse sales practices. The research results showed that there are statistically significant $(\mathrm{p}<0.05)$ differences on the sales revenues of the GDF due to accession rate of appraised value consisting of the RDF, FED, stumpage sales or traditional warehouse sales, and the year and month variables in which forest products are offered for sale. Likewise, it has been detected that the proximity of FEDs, which regulate wood-based product sales, to the high-capacity forest products industry managements in terms of accessibility with regard to geographical location has a significant effect on sales revenues.
\end{abstract}

Keywords: Accession Rate of Appraised Value, Geographical Proximity, Stumpage Sales, Warehouse Sales

$\ddot{O} z$

Türkiye orman ürünleri pazarında tekel özelliğini kaybetmesi Orman Genel Müdürlüğünün gelirlerinin azalmasına neden olmuştur. Devlet Orman Isşletme Müdürlükleri (DOIM) odun emvali satış ihalelerini münferit olarak düzenlemekte ve her işletmenin başarı düzeyi yine münferit olarak değerlendirilmektedir. Bu çalışmada, Orman Genel Müdürlüğ̈̈nün odun esaslı ürünler için satış fiyatını etkileyen bazı faktörler analiz edilmiştir. Bu kapsamda, coğrafi konum yönünden birbirine yakın 2 Orman Bölge Müdürlüğ̈̈ ve bunlara bağll olarak faaliyet gösteren 21 DOIM'in 2014-2018 yılları arasındaki 5 yıllık odun emvali satış ihalesi sonuçları incelenmiştir. Değerlendirmeler dikili ăgaç satışı ve geleneksel depodan satış uygulamaları temelinde gerçekleştirilmiştir. Araştırma sonuçları, Orman Bölge Müdürlüğ̈̈, DOIM, satışların dikili ă̆aç satışı veya geleneksel depo satışları olması, orman ürünlerinin satışa sunulduğu yıl ve ay değişkenlerinin oluşan Muhammen Bedel Artırma Oranı dolaylsıyla Orman Genel Müdürlügünün satış gelirleri üzerinde istatistiksel düzeyde anlamlı $(p<0.05)$ farklılıklar oluştuğunu göstermiştir. Benzer şekilde, odun esaslı ürün satış ihalesi düzenleyen DOIM'lerin ulaşılabilirlik yönünden coğrafi konum itibariyle yüksek kapasiteli orman ürünleri endüstrisi işletmelerine olan yakınlı̆̆ının elde edilen satış gelirleri üzerinde önemli düzeyde etkisinin bulunduğu tespit edilmiştir.

Anahtar kelimeler: Muhammen Bedel Artırma Oranı, Coğrafi Yakınlık, Depodan Satış, Dikili Satış

\footnotetext{
*a Osman KOMUT; osmankomut@gumushane.edu.tr, orcid.org/0000-0002-8390-7884

${ }^{\mathrm{b}}$ orcid.org/0000-0002-5742-4416
} 


\section{Introduction}

The sustainability of forest resources around the world has been become a rapidly developing issue after the 1990s. In addition to the sustainability of the forest assets, the supply enough to meet the forest products demand and the continuity of the sales revenues that would be obtained are also important. On the other hand, many studies have been concluded that reached to the conclusion that the forest products supply should be regulated according to market demand (McKillop, 1967; Leuschner, 1973; Robinson, 1974; Buongiorno, 1977; Buongiorno, 1978; Kayacan et al., 2012). Changing market conditions and consumer behavior indirectly affect forest enterprises (Halaj et al., 2018). Wood based products are the most important source of income for forest enterprises (Sujová et al., 2017).

The wood based raw material production in manufacturing of forest resources in Turkey has been considered as the main purpose of General Directorate of Forests (GDF) until the recent past. Therefore, developing the qualification of these products, the activity and efficiency aspects of actions were ignored. However, developing market conditions have increased the importance of these issues for forest industry managements (Sedjo and Sohngen, 1996; Öztürk et al., 2011).

The wood raw material supply of Forest Enterprises Directorate (FED) within the structure of Regional Directorate of Forests (RDF) also constitutes the main output of the revenue plans based on the sustainable management approach of forest resources. On the other hand, disasters such as natural disasters, storms and fires are known to have an impact on the supply of wood raw materials. Especially changes in the construction sector, furniture and paper industry and the process with ups and downs due to the general economic situation are an important factor on the demand for wood raw materials, In the current market conditions, it is important that wood based raw material and semi-finished producers concentrate on developing new resources and methods that can minimize the impact level from environmental factors (İlter and Ok, 2007; Özler, 2013).

Foreign trade policies, which have been implemented after the 1990s in Turkey, distracted FEDs away from the position of being the only supplier of forest products and reductions in income of these manufactures has been occurred. Especially in the marketing of wood-based forest products which are not possible for FEDs to remove from product mix, new quests have become inevitable. Losing monopoly feature of GDFs, which are given manufacturing of forest products in Turkey by laws, has increased the importance of the wood raw material production, creation of product mix suitable for the market, cost and pricing, distribution and promotional activities (İlter, 1985; Türker, 1996; Demirel, 2006; Komut, 2011).

This study aims to evaluate the change of the accession rate of appraised value according to some factors in auction sales for 2 different and adjacent RDFs and affiliated FEDs in comparison with stumpage sales and warehouse sales applications. Evaluation variables were determined as; RDF, FED, years, months and proximity to important industrial facilities.

\section{Materials and Methods}

Amasya RDF and Giresun RDF, which are similar in terms of climate and habitat characteristics and have geographical proximity, were selected as the study area. Both RDFs have similar characteristics in terms of management scale and operation area of forest industry managements that constitute their target markets.

There are 11 FED within Amasya RDF and 10 FED in Giresun RDF. FEDs in Amasya RDF responsibility area are as follows; Bafra, Vezirköprü, Samsun, Karg1, İskilip, Amasya, Çorum, Erbaa, Tokat, Niksar, Almus (Figure 1). FEDs in Giresun RDF responsibility area are as follows; Akkuş, Ünye, Ordu, Giresun, Dereli, Espiye, Tirebolu, Mesudiye, Koyulhisar, Şebinkarahisar (Figure 1). The forest industry facility with the highest capacity in Amasya RDF responsibility area is located in Vezirköprü FED responsibility area. The forest industry facility with the highest capacity in Giresun RDF responsibility area is located in Ordu FED responsibility area. Other FEDs are grouped as to first degree and second degree close according to accessibility criteria (Figure 1).

In this study, data on Amasya and Giresun RDF's stumpage sales and traditional warehouse sales concerning 2014-2018 wood assets sales and auction sales were utilized. Data for the period in question was obtained from Amasya RDF and Giresun RDF records. There are significant differences between the forest area sizes of both RDFs. However, the amount of stumpage sales and industrial wood sales in 2018 are similar (Table 1) (OGM, 2019b). 


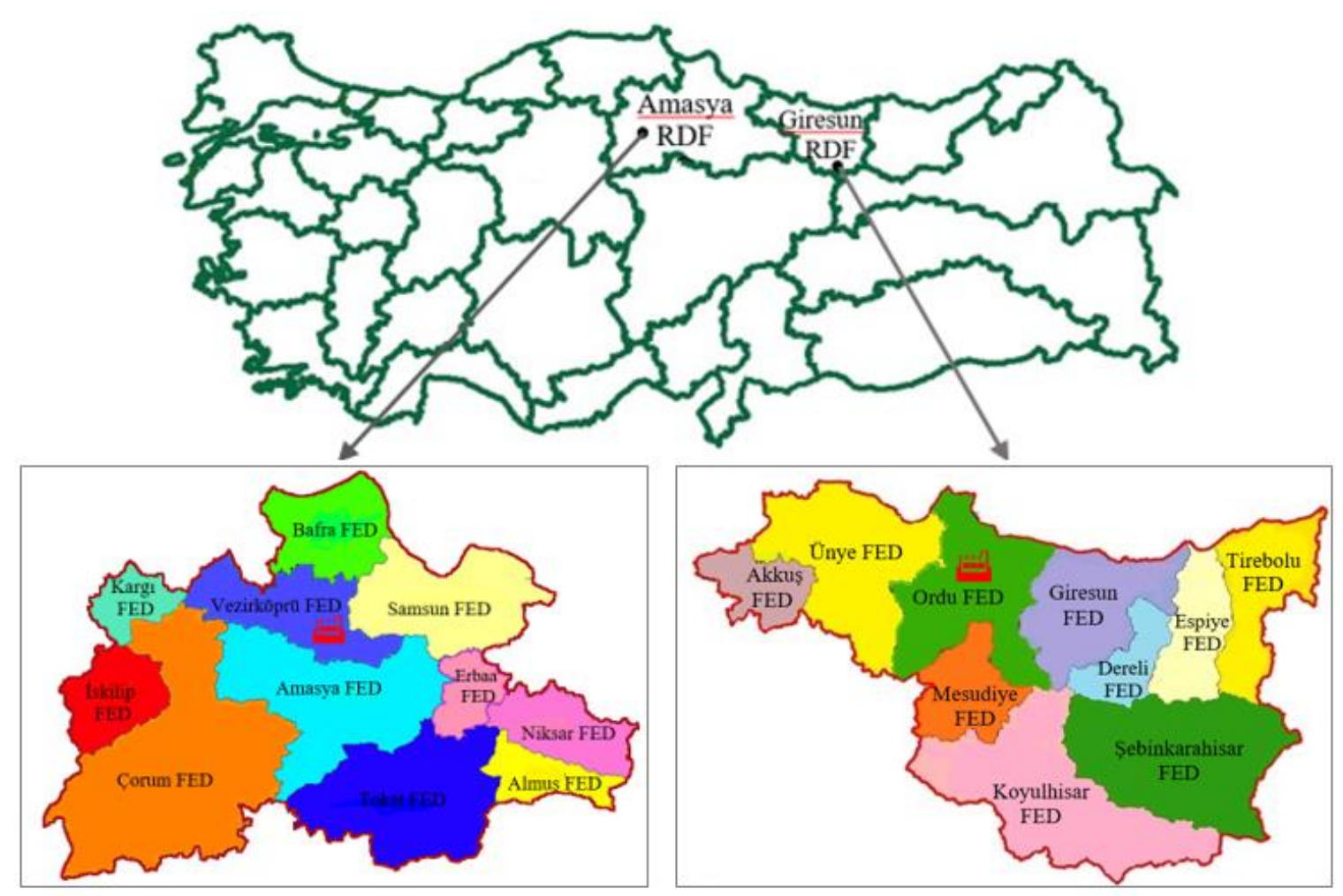

Figure 1. Study area and FED distribution (OGM, 2019a)

Table 1. General characteristics of sample RDFs

\begin{tabular}{ccccc}
\hline RDF & $\begin{array}{c}\text { General Forest Area } \\
(\mathbf{h a})\end{array}$ & $\begin{array}{c}\text { Stumpage Sales } \\
\left(\mathbf{m}^{\mathbf{3}}\right)\end{array}$ & $\begin{array}{c}\text { Industrial Wood Sales } \\
\left(\mathbf{m}^{\mathbf{3}}\right)\end{array}$ & $\begin{array}{c}\text { Firewood Sales } \\
(\mathbf{S t e r})\end{array}$ \\
\hline Amasya & 1529275 & 263000 & 994000 & 338000 \\
Giresun & 560810 & 242000 & 729000 & 96000 \\
Total & 2090085 & 505000 & 1723000 & 434000 \\
\hline
\end{tabular}

Years, months and the Accession Rate of Appraised Value (ARAV) based on FED are determined with Equation 1 for the stumpage sales and traditional warehouse sales auctions on the basis of RDFs.

$A R A V=\left[\frac{S P-A V}{A V}\right] X 100$

Where ARAV is accession rate of appraised value (\%), SP is sales price $\left(\$ / \mathrm{m}^{3}\right), \mathrm{AV}$ is appraised value $\left(\$ / \mathrm{m}^{3}\right)$.

SPSS package program was utilized for statistical comparisons between ARAVs estimated in the study. Kolmogorov-Smirnov Test was applied to the obtained data and the data was determined to show normal distribution. Therefore, parametric tests were applied in the analyses. According to this, one-way analysis of variance (ANOVA) was used in comparisons where dependent and independent variables were present and the number of variables was above two. One of the non-parametric tests, Mann-Whitney U Test was used in comparisons with two independent variables where the sample number was less than 30.

\section{Results and Discussion}

The ARAV average of Amasya RDF's stumpage sales between years 2014-2018 has been determined as $15.13 \%$. Despite the decline in 2015, ARAV has been found to have an overall increase tendency (Table 2). The highest ARAV among FEDs has occurred in the Amasya FED. 
Table 2. ARAV for Amasya RDF stumpage sales in regards to years

\begin{tabular}{|c|c|c|c|c|c|c|c|}
\hline \multirow{2}{*}{ FED } & \multicolumn{5}{|c|}{ ARAV by Years (\%) } & \multirow{2}{*}{$\begin{array}{l}\text { Standard } \\
\text { Deviation }\end{array}$} & \multirow{2}{*}{ Average (\%) } \\
\hline & 2014 & 2015 & 2016 & 2017 & 2018 & & \\
\hline Çorum & 3.56 & 5.34 & 0.68 & 4.39 & 8.27 & 2.76 & 4.45 \\
\hline Amasya & 61.54 & 30.68 & 38.85 & 72.03 & - & 19.27 & 50.78 \\
\hline Tokat & 24.41 & 0.11 & 16.69 & 5.23 & 47.49 & 18.66 & 18.79 \\
\hline Vezirköprü & 0.18 & 1.45 & 6.67 & 8.62 & 10.55 & 4.51 & 5.49 \\
\hline Samsun & 29.96 & 1.78 & 8.67 & 16.65 & 13.44 & 10.49 & 14.10 \\
\hline Bafra & 1.00 & - & - & 16.79 & 6.76 & 7.99 & 8.19 \\
\hline Niksar & 1.50 & - & 3.25 & 25.07 & 16.74 & 11.25 & 11.64 \\
\hline Almus & 0.18 & 0.18 & 5.29 & 0.08 & 3.52 & 2.42 & 1.85 \\
\hline İskilip & 0.83 & 7.03 & - & - & 0.57 & 3.66 & 2.81 \\
\hline Karg1 & 0.10 & 0.27 & 0.15 & 7.56 & 35.95 & 15.51 & 8.81 \\
\hline Erbaa & 11.57 & 34.20 & 70.19 & - & 42.27 & 24.21 & 39.55 \\
\hline Average $(\%)$ & 12.26 & 9.00 & 16.71 & 17.38 & 18.56 & 4.02 & 15.13 \\
\hline
\end{tabular}

The ARAV average concerning the stumpage sales of Giresun RDF between years 2014-2018 has been determined as $8.11 \%$. Like Amasya RDF, ARAV has been determined to be in an overall increase tendency despite the decline in 2015 (Table 3). The highest ARAV among FEDs was observed in Koyulhisar FED.
In general, ARAV values occurred higher in Amasya RDF when compared with Giresun RDF. After the decrease in ARAV in 2015, both RDFs have showed an increase tendency. The general increase-decrease tendency in the related process was observed to be similar for both units (Figure 2).

Table 3. ARAV for Giresun RDF stumpage sales in terms of years

\begin{tabular}{cccccccc}
\hline \multirow{2}{*}{ FED } & \multicolumn{9}{c}{ ARAV by Years (\%) } & \multicolumn{2}{c}{$\begin{array}{c}\text { Standard } \\
\text { Deviation }\end{array}$} & Average (\%) \\
\cline { 2 - 5 } & $\mathbf{2 0 1 4}$ & $\mathbf{2 0 1 5}$ & $\mathbf{2 0 1 6}$ & $\mathbf{2 0 1 7}$ & $\mathbf{2 0 1 8}$ & \\
\hline Koyulhisar & 40.03 & - & - & 0.58 & - & 27.90 & 20.31 \\
Şebinkarahisar & - & - & - & - & 0.92 & & - \\
Giresun & 6.48 & 8.17 & 0.47 & 29.78 & 6.86 & 11.26 & 10.35 \\
Ünye & 6.90 & 1.69 & 5.42 & 2.43 & 8.10 & 2.78 & 4.91 \\
Ordu & 0.60 & 1.97 & 3.60 & 17.19 & 50.68 & 21.12 & 14.81 \\
Mesudiye & 31.08 & 6.63 & 4.83 & 8.59 & 18.69 & 10.97 & 13.96 \\
Tirebolu & 20.67 & 1.52 & 6.73 & 0.36 & 2.06 & 8.41 & 6.27 \\
Espiye & 12.93 & 1.23 & 1.47 & 5.43 & - & 5.46 & 5.27 \\
AkkuS & - & 0.56 & - & - & - & - & 0.56 \\
Dereli & 0.38 & 0.36 & 1.96 & 0.87 & 14.89 & 6.29 & 3.69 \\
Average (\%) & 14.88 & 2.77 & 350 & 8.15 & 14.60 & 5.82 & 8.11 \\
\hline
\end{tabular}

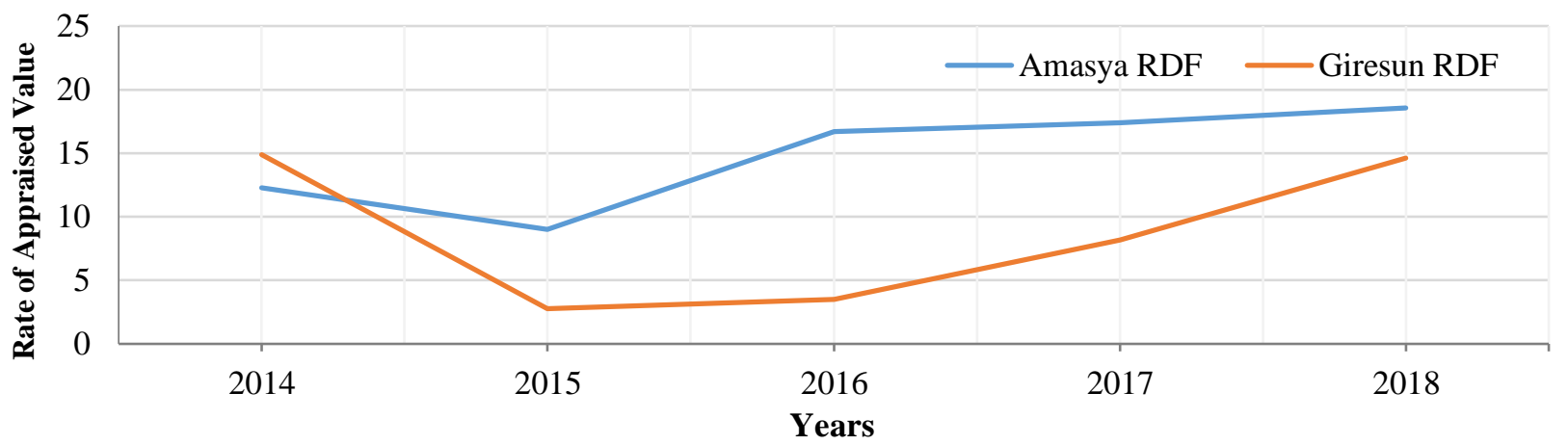

Figure 2. ARAV comparison at RDFs level

On the other hand, statistically significant differences were found between the averages of ARAV values on a monthly basis (Table 4). According to this, ARAV values in Amasya RDF have occurred higher than Giresun RDF. This difference can be attributed to the fact that the large industrial facility in the Amasya RDF area of responsibility is a facility that produces different products such as timber, MDF, particleboard, plywood. 
Table 4. Mann-Whitney U test results concerning Amasya RDF and Giresun RDF ARAV values

\begin{tabular}{cccccccc}
\hline \multirow{2}{*}{ Factor } & RDF & $\begin{array}{c}\text { Number } \\
(\mathbf{N})\end{array}$ & Mean Rank & $\begin{array}{c}\text { Mann- } \\
\text { Whitney U }\end{array}$ & $\begin{array}{c}\text { Wilcoxon } \\
\text { W }\end{array}$ & Z & p \\
\hline \multirow{2}{*}{ ARAV } & Giresun & 12 & 8.670 & & & & \\
& Amasya & 12 & 16.330 & 26.000 & 104.000 & -2.656 & $0.008^{*}$ \\
& Total & 24 & & & & & \\
\hline
\end{tabular}

ARAV values of Amasya and Giresun RDF's 5year stumpage sales on a monthly basis are given in Figure 3. It is deducted that there has been an increase in ARAV values in April, May and June and a decrease tendency in sales after June is observed. It was observed that the monthly ARAV changes which show similar characteristics in both RDFs were observed to be more pronounced in Amasya RDF (Figure 3).

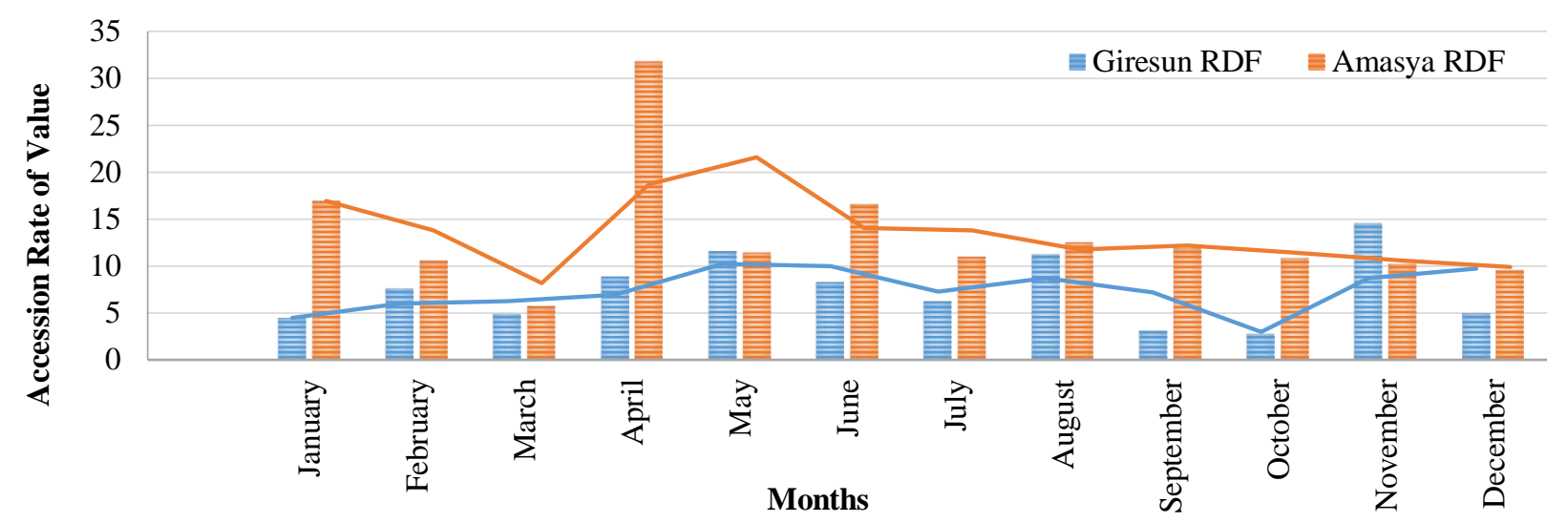

Figure 3. Average 5-year ARAV values on the basis of months

The ARAV relationship formed with 1 st and 2nd degree proximity to high capacity forest industry managements and accessibility characteristics of FEDs affiliated to RDFs is given in Figure 4. According to this, it was found that products of FEDs, which are accessible in terms of forest industry managements and considered to have low raw material transportation cost, are shown more interest towards their products. Therefore, it has been found that ARAV is formed at a higher level in FEDs which are 1st degree close to forestry managements in both RDFs.

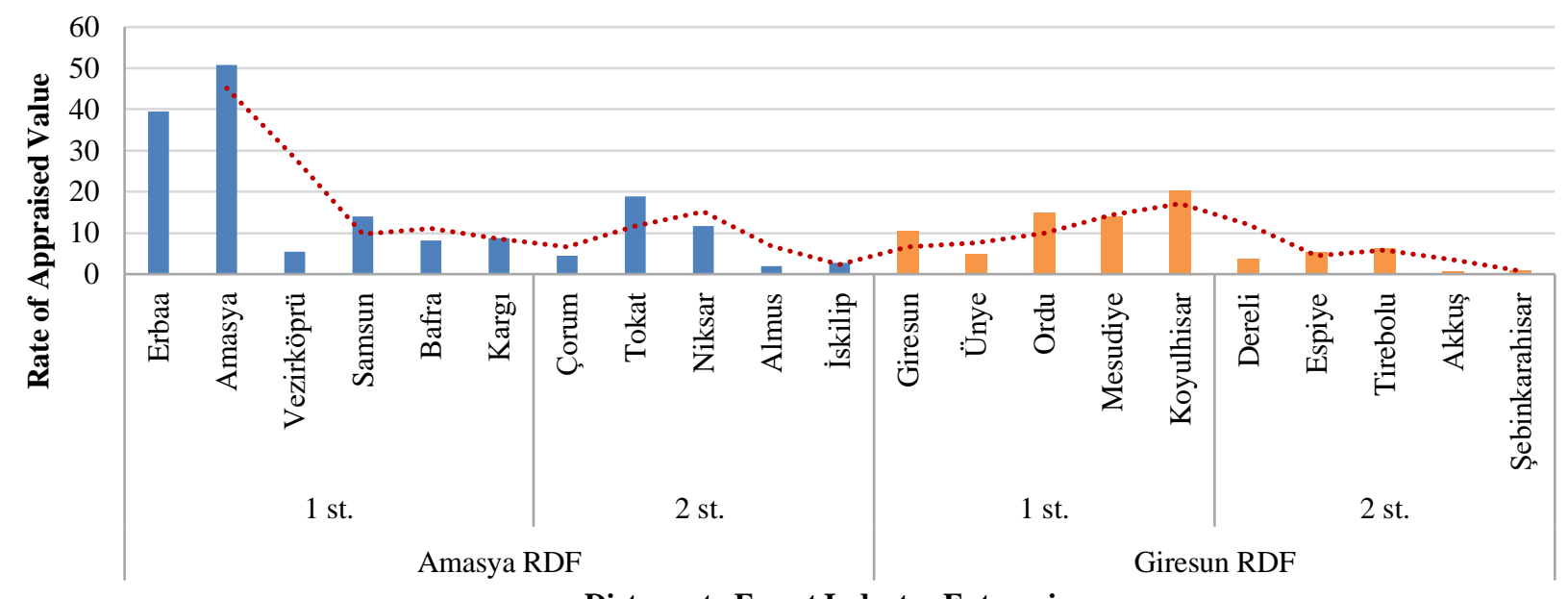

Distance to Forest Industry Enterprises

Figure 4. Relationship of distance to forest industry enterprises with ARAV

At the level of FEDs affiliated with Amasya and Giresun RDFs, timber, industrial wood and paper wood product classes sales were used as base in the evaluation of wood based products from traditional warehouse. In the One-Way Analysis of Variance, statistically significant differences 
were determined between the FEDs affiliated with Amasya RDF in terms of average ARAV value $(\mathrm{p}<0.05)$. On the other hand, the analysis results showed that there was no statistically significant difference between FEDs affiliated with Giresun RDF ( $p>0.05)$ (Table 5).

Table 5. Results of ARAV One-Way Analysis of Variance in wood assets sales on the basis of FED

\begin{tabular}{|c|c|c|c|c|c|}
\hline Variables & FED & $\mathbf{N}$ & $\mathbf{M}$ & $\mathbf{F}$ & Sig. \\
\hline \multirow{12}{*}{ Amasya RDF ARAV } & Corum & 9 & 0.203 & \multirow{12}{*}{2.105} & \multirow{12}{*}{$0.032 *$} \\
\hline & Amasya & 8 & 0.171 & & \\
\hline & Tokat & 9 & 0.116 & & \\
\hline & Vezirköprü & 8 & 0.282 & & \\
\hline & Samsun & 10 & 0.191 & & \\
\hline & Bafra & 10 & 0.348 & & \\
\hline & Niksar & 10 & 0.116 & & \\
\hline & Almus & 10 & 0.197 & & \\
\hline & İskilip & 6 & 0.207 & & \\
\hline & Kargi & 9 & 0.149 & & \\
\hline & Erbaa & 8 & 0.191 & & \\
\hline & Total & 97 & 0.197 & & \\
\hline \multirow{11}{*}{ Giresun RDF ARAV } & Koyulhisar & 3 & 0.236 & \multirow{11}{*}{0.676} & \multirow{11}{*}{0.722} \\
\hline & Șebinkarahisar & 2 & 0.300 & & \\
\hline & Giresun & 4 & 0.244 & & \\
\hline & Ünye & 3 & 0.099 & & \\
\hline & Ordu & 4 & 0.276 & & \\
\hline & Mesudiye & 4 & 0.230 & & \\
\hline & Tirebolu & 4 & 0.215 & & \\
\hline & Espiye & 1 & 0.079 & & \\
\hline & Akkuş & 3 & 0.264 & & \\
\hline & Dereli & 4 & 0.247 & & \\
\hline & Total & 32 & 0.229 & & \\
\hline
\end{tabular}

$* \mathrm{p}<0.05$

ARAV relationship with 1 st and 2nd degree proximity to high capacity forest industry managements and accessibility characteristics in the traditional warehouse sales of wood based products is given Figure 5. According to this, it was determined that proximity and accessibility to forest industry management increased ARAV value in warehouse sales, similar to stumpage sales.

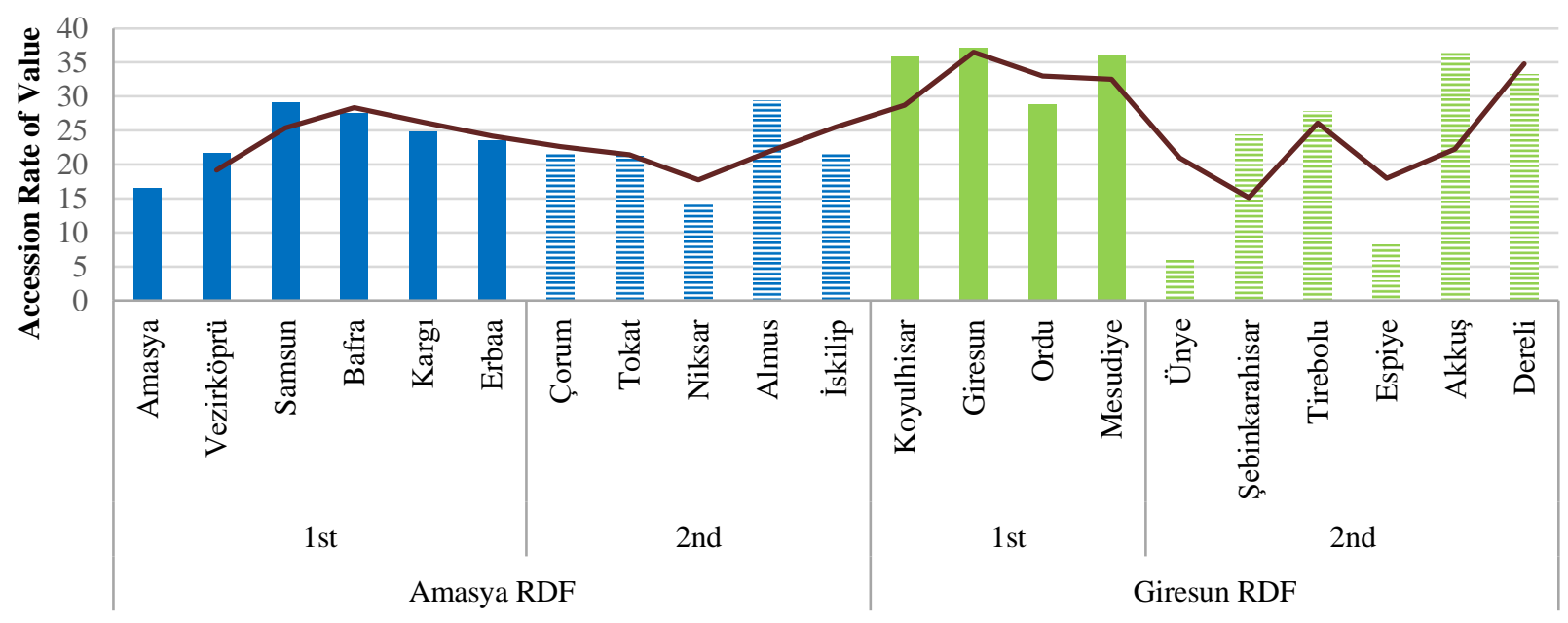

Figure 5. ARAV relationship with forest industry enterprises in warehouse sales

In this research, ARAV has been determined to be affected by the variables of RDF, FEDs within RDF, sale month and sale year. It has been stated that stumpage sales, which are developed as an alternative to warehouse sales, have not yet been implemented efficiently and effectively and include some economic and technical problems (Daşdemir, 2011). In a study, it was reported that 
the number of buyers in the stumpage sales application was lower than that of warehouse sales, thus decreasing competition and lowering the revenues of FEDs (Komut and Öztürk, 2014). There are studies stating that economic fluctuations occurring in the country and in the world markets lead to differentiation in the production and sales of wood raw materials by years (İlter and Ok, 2007; Özler, 2013; Daşdemir, 2003; Dikilitaş and Öztürk, 2010; Buğday, 2016). In a study on the subject, it was concluded that differentiating the tender times of FEDs will have an increasing effect on revenues (Ok, 1997).

The findings obtained in this study show similarities to the literature on sales revenues of FEDs. In this study, it was determined that the variables like product type, tree type, proximity to FED industrial facilities that go out to tender, and auction times variables were found to lead to significant differences in terms of revenue generated because of ARAV, which is generated by traditional warehouse sales. It was reported that FEDs produced wood-based products at different times during the year affected the production costs and sales revenues of the managements (Ok, 1997).

Another study has shown that the cost and revenue characteristics of wood-based products in FEDs' sales warehouses are influenced by the product quality as well as the distance to forest industry enterprises that are buyers of these products (Türker, 2013). In addition, many studies have been conducted stating that the supply of forest products should be planned according to the demand in the market (McKillop, 1967; Leuschner, 1973; Robinson, 1974; Buongiorno, 1977; Buongiorno, 1978; Kayacan et al., 2012). Studies proves that the prices of forest products depend on the supply-demand balance in the market and consumption of wood products per capita (Zivnuska, 1955; Holland, 1960; Kayacan and Öztürk, 2009). On the other hand, it has been reported that the effect of aspects like obtaining high revenue in forest products marketing, auction times, the status of forest industry managements and seasonal changes on the prices should be determined with the right strategy (Trømborg et al., 2000). In addition, it is reported that volatile supply and demand in the markets in the future necessitates efforts to increase the flexibility of the forestry sector (Jonsson, 2011; Sahoo et al., 2019; Poudyal et al., 2019). However, it is reported that GDF cannot act independently on pricing of forest products based on market and cost conditions (Daşdemir, 2003).

\section{Conclusions}

The results of the research showed that the variables of RDF, FED, auction year, auction month and proximity to forestry industry managements had an impact on ARAV formed as a result of the auction and significantly differentiated the revenue obtained.

Evaluations conducted have emerged the product types and procurement policies required by forestry industry managements as an important factor affecting the income generated by FEDs from forestry product sales. It has been observed that transportation costs have significant effects on purchasing decisions of these managements as well as product price. As the proximity and accessibility to forestry industry managements in terms of geographical location of the products supplied to the market increases, the potential to generate more revenue also increases.

The results of the study clearly showed that RDFs should actively use the coordination function in order to enable the FEDs to act jointly with respect to the times of wood assets auctions. On the other hand, in order for GDF to increase its sales revenues, it is found necessary to make plans for the auction time at RDFs level.

\section{Acknowledgments}

This study is a part of a master thesis entitled "Variation of Rate of Appraised Value in Auction Sales According to some Factors: The Case of Amasya and Giresun Forest Regional Directorates" prepared by Serpil SANTO under the supervision of Assistant Professor Dr. Osman KOMUT in Gumushane University.

\section{References}

Buğday, S.E., 2016. Oduna Dayalı Orman Ürünlerinde Stratejik Pazarlama Analizi (Kastamonu Orman Bölge Müdürlüğü Örneği). Doktora Tezi, Çankırı Karatekin Üniversitesi Fen Bilimleri Enstitüsü. Çankırı, 300p.

Buongiorno, J., 1977. Long-term Forecasting of Major Forest Products Consumption in Developed and Developing Countries. Forest Science, 23(1), 13-25.

Buongiorno, J., 1978. Income and Price Elasticities in the World Demand for Paper and Paperboard. Forest Science, 24(2), 231-246.

Daşdemir, İ., 2003. Asli Orman Ürünlerinde Fiyat Analizi (Zonguldak Orman Bölge Müdürlüğü 
Örneği), ZKÜ Bartın Orman Fakültesi Yayınları, Üniversite Yayın No: 26, Fakülte Yayın No: 12. Bartın, 119p.

Daşdemir, İ., 2011. Dikili Ağaç Satışlarının Uygulanması Üzerine Değerlendirmeler. Bartın Orman Fakültesi Dergisi, 13(20), 71-79.

Demirel, E., 2006. Açık Artırmalı Tomruk Satışlarında Fiyat Oluşum Sürecinin İncelenmesi (Kahramanmaraş Orman Bölge Müdürlüğü Örneği). Yüksek Lisans Tezi, Zonguldak Karaelmas Üniversitesi Fen Bilimleri Enstitüsü. Bartın, 99p.

Dikilitaş, K. and Öztürk, A., 2010. Artvin Orman Bölge Müdürlüğü Son Beş Yıllık Açık Artırmalı Satışlarının İrdelenmesi. III. Ulusal Karadeniz Ormanc1lı Kongresi, 20-22 May1s 2010, Artvin, 259-269.

Halaj, D., Sedliačiková, M. and Malá, D., 2018. Customer Behavior on the Slovakian Roundwood Market: A Case Study. BioResources, 13(3), 6003-6020.

Holland, I., 1960. An Explanation of Changing Lumber Consumption and Prices. Forest Science, 6(2), 171-192.

İlter, E., 1985. Orman Ürünleri Pazarlaması: Ankara, Çă̆ Matbaası, 273p.

İlter, E. and Ok, K.,2007. Ormancilik ve Orman Endüstrisinde Pazarlama İlkeleri ve Yönetimi: Ankara, Form Ofset Bask1, 488p.

Jonsson, R., 2011. Trends and Possible Future Developments in Global Forest-Product Markets-Implications for the Swedish Forest Sector. Forests, 2(1), 147-167.

Kayacan, B. and Öztürk, A., 2009. Dünyada Orman Ürünleri Piyasa Modelleri: Gelişim Süreci ve Türkiye Için Yönelimler. Ormancıllkta SosyoEkonomik Sorunlar Kongresi, 19-21 Şubat 2009, Isparta, 152-165.

Kayacan, B., Ucal, M., Öztürk, A., Balı, R., Koçer, S. and Kaplan, E., 2012. Modeling and Forecasting the Demand for Industrial Roundwood in Turkey: A Primary Econometric Approach. Journal of Food Agriculture and Environment, 10(2), 1127-1132.

Komut, O., 2011. Sarıçam Tomruklarında Mavi Renklenme Zararı ve Satış Fiyatı Üzerine Etkileri. Yüksek Lisans Tezi, Artvin Çoruh Üniversitesi Fen Bilimleri Enstitüsü. Artvin, 98p.

Komut, O. and Öztürk, A., 2014. Dikili Ağaç Satış1 Uygulamasının Yerel Piyasadaki Rekabete Etkileri. II. Ulusal Akdeniz Orman ve Çevre
Sempozyumu, 22-24 Ekim 2014, Isparta, 10681074.

Leuschner, W.A., 1973. An Econometric Analysis of the Wisconsin Aspen Pulpwood Market. Forest Science, 19(1), 41-46.

McKillop, W.L.M., 1967. Supply and Demand of Forest Products: An Econometric Study. Hilgardia, 38(1), 1-132.

OGM, (2019a). T.C. Tarım ve Orman Bakanlığı, Orman Genel Müdürlüğü https://www.ogm.gov.tr/Sayfalar/OrmanBolge Mudurlukleri.aspx.

OGM, (2019b). T.C. Tarım ve Orman Bakanlığ1 Orman Genel Müdürlüğü 2019 Performans Programı. Strateji Geliştirme Daire Başkanlığı, Ankara.

Ok, K., 1997. Devlet Orman İşletmelerinin Açık Artırmalı Satışlarının Etkileşimi. DOA Dergisi, 3, 39-62.

Özler, T., 2013. Isparta Orman Bölge Müdürlüğü’nde Dikili Ağaç Satışlarının Değerlendirilmesi. Yüksek Lisans Tezi, Süleyman Demirel Üniversitesi Fen Bilimleri Enstitüsü. Isparta, $119 \mathrm{p}$.

Öztürk A., Kayacan B. and Dikilitaş, K., 2011. A Linear Price Model for Insect-damaged Industrial Roundwood: A Case Study in Northeastern Turkey. African Journal of Business Management, 5(21), 8552-8557.

Poudyal, B.H., Maraseni, T.N. and Cockfield, G., 2019. Implications of Selective Harvesting of Natural Forests for Forest Product Recovery and Forest Carbon Emissions: Cases from Tarai Nepal and Queensland Australia. Forests, 10(8), 693.

Robinson, V.L., 1974. An Econometric Model of Softwood Lumber and Stumpage Markets 194767. Forest Science, 20(2), 171-179.

Sahoo, K., Bergman, R., Alanya-Rosenbaum, S., Gu, H. and Liang, S., 2019. Life Cycle Assessment of Forest-based Products: A Review. Sustainability, 11(17), 4722.

Sedjo, R. and Sohngen, B., 1996. A Comparison of Timber Models for use in Public Policy Analysis. Resources for the Future 1996, Discussion Paper 96-12, Washington DC, USA.

Sujová, A., Michal, J., Kupčák, V. and Dudík, R., 2017. The Impact of International Trade of Raw Wood to the Economic Growth of Forest-Based Sectors in the Czech and Slovak Republics. BioResources, 12(1), 1102-1111. 
Trømborg, E., Buongiorno, J. and Solberg, B., 2000. The Global Timber Market: Implications of Changes in Economic Growth, Timber Supply and Technological Trend. Forest Policy and Economics, 1(1), 53-69.

Türker, M.F., 1996. Investigation of Price Formation in Auction Forest Products (logs) Sales (Case of Eastern Black Sea Region). Postdoctoral
Research, KTU Research Fund 93.115.002.1, Trabzon, Turkey.

Türker, M.F., 2013. Ormancılık İşletme Ekonomisi. Güncellenmiş ve Genişletilmiş 2. Baskı, Ormancılık ve Tabiatı Koruma Vakfı Yayın No:5, Trabzon, 287p.

Zivnuska, J.A., 1955. Supply, Demand and the Lumber Market. Journal of Forestry, 53(8), 547-553. 